\title{
Group counseling as self-management intervention for former mental health patients: A case study
}

\author{
Abu Yazid Abu Bakar ${ }^{1 *}$, Nurul Anis Azizi ${ }^{2}$, Siti Khadijah Hashim ${ }^{3}$ \\ ${ }^{123}$ Universiti Kebangsaan Malaysia, Malaysia
}

\begin{tabular}{l}
\hline \hline Article Info \\
\hline Article history: \\
Received Jan $20^{\text {th }}, 2020$ \\
Revised Feb $10^{\text {th }}, 2020$ \\
Accepted Feb $20^{\text {th }}, 2020$ \\
\hline
\end{tabular}

\section{Keyword:}

Group counselling; mental health patients, self-management

\begin{abstract}
The aim of the study conducted in order to help and to give exposure for the group members on how to build self-confidence in facing society. Three objectives of the study are 1) to build self-confidence among group members on how to face society, 2) to encourage and to give support in self-motivation towards well-being among group members and 3) to give awareness for the group members that this life needs courage and positive thoughts which are more meaningful. The method of this study was conducted a group counselling session involving six mental health patients who are recovered and still under doctor observation at the Hospital Canselor Tuanku Mukhriz (HCTM), which is under the Day Care Community Psychiatry, Medical Centre and Faculty of Medicine, Universiti Kebangsaan Malaysia (UKM). The findings show that the responsiveness of respondents' self-management is still lacking as they are still in the process of recovering and monitoring from Psychiatrists and Counsellor Officers at HCTM for time to time.
\end{abstract}

\section{Corresponding Author:}

Abu Yazid Abu Bakar

Universiti Kebangsaan Malaysia, Malaysia

Email: yazid3338@ukm.edu.my

\section{Introduction}

Mental health describes about different social adaptations according to the place and time that the individual has at various levels as a position or, to what extent, does the individual successfully adjust internally between his or her various motivators and proponents as well as externally in relation to the nature and surroundings including living or non-living things.

Therefore, there are some significant indicators for measuring an individual's mental health, which are the individual realistic acceptance of his or her limitations, willingness to enjoy social relationships, success and willingness to work, life passion, ability to cope with frustration, life views, wide psychological, the ability to expand his or her movement and needs, the attitude reliability, and willingness to take risk of his or her actions and decisions (Roslee, Mohamed Sharif \& Jamaludin 2005).

Based on the results of a study conducted by Porter, Spates and Smitham (2004), it explains that depression is one of the most common mental illnesses in mental health practice. In this study, a treatment to cure depression is called Behavioural Activation Group Therapy (BAGT) has emerged to manage depression with a combination of psychological approaches in which mental illness behaviours are viewed over time as a recovery treatment process. In addition, this study examined the effects of Behavioural Activation Group Therapy (BAGT) on depression in public mental health settings. The results indicate that BAGT can respond positively to the respondents - patients experiencing natural behavioural changes - and indirectly save on the cost of treatment when using this treatment approach. 
A study conducted by Powell and Perron (2010) explains that self-support groups for mental health patients are very important in the management of well-being. The researchers also stated that patients' social relationships with support groups could lead to recovery with a healthy social environment and relationships. In addition, formal treatment that helps in the recovery of patients and indirectly with the support group can also encourage for the healing of the patient. Therefore, this case study emphasizes that the support group is a support system and a proponent for the recovery of mental patients in achieving a healthier mental health.

A case study conducted by Ahmad Nabil, Marhani and Azlin (2014), found that a holistic approach to Assertive Community Care (ACT) could help to reduce hospitalization risk and improve disease control and the quality of life together. In addition, the symptoms of schizophrenia caused explicit costs to the patient's distress and burden to his or her caregiver, thus, psychiatric services have been proven to be inadequate in providing comprehensive care for those with mental illness as a whole and in need of other support. Therefore, this case study suggests that the burden of families of schizophrenic patients can be reduced with the Assertive Community Care (ACT) approach to improve the quality of life and the condition of these patients.

This research focused on the community of mental health patients who are still under doctor observation at Hospital Canselor Tuanku Mukhriz (HCTM), under the Day Care Community Psychiatry, Medical Centre and Faculty of Medicine, Universiti Kebangsaan Malaysia (UKM). This group counselling session is being conducted on mental health patients in order to achieve their ultimate goal of sharing information about selfmanagement, building self-confidence in the community, encouraging and supporting them in motivating themselves towards well-being, providing awareness that life requires courage and positive thoughts to be more meaningful and to motivate themselves by seeing their dreams that need to be achieved.

According to the case study of Intan Nurhaila, Norlija, Nur Falihin, Mohamad Haazik and Mohd Yusof (2011), mental health is a very important aspect of every phase of human life as much as physical health. Mental health is seen from both the good and the bad aspects. Sometimes, one has a very healthy mental state, but at other times it is the opposite. When experiencing mental health problems, an individual needs the help of others to deal with the problems they are facing. Mental health can have an impact on a person's daily or future lives including children and youth. Treating and protecting the mental health of children and youth is an important aspect that can contribute to better individual development in the future. The objective of this study was to examine whether there is a significant relationship between the gender, race and religion of youth with their level of mental health knowledge. Therefore, it is in line with the current needs of this study to look at the level of knowledge about mental health among students of the institution of higher learning.

\section{Method}

This study is a qualitative study using a phenomenological approach. Phenomenological studies are studies used to analyse human experience (Muhammed Arba'in, 2012). This study has selected six former mental health patients who were still in treatment. The participants were selected by using purposive sampling procedure. Participants between the ages of 25 and 40 years were treated and controlled with follow-up medication from a specialist doctor and counsellor in the psychiatric department. The data of this study were collected using in-depth interview technique, while session observation and written report became the supporting method to triangulate the data

\section{Results and Discussions}

The group counselling conducted on the respondents has a predetermined purpose. According to psychologists at HCTM, these patients are still taking medications to solve their problems and remain in normal condition like everyone else. Therefore, several group counselling sessions were conducted to identify and explore the issues faced by these patients to study the extent of their lives as former mental patients. Five group counselling sessions are conducted in a therapeutic and comfortable room. The implementation of the group counselling session was carried out in several stages in table 1

Generally, group counselling services can be one of the support systems for former mental health patients from all aspects of life, especially recognizing that self-management needs to be managed in pursuing selfreliance and rising self-motivation to achieve better living. In addition, the supportive environment in this group can also make group members more confident in learning and practicing new behavior learned through this group. Group members will be able to learn new social skills as well as improve existing social skills as well as helping them to interact in healthy ways. 
Table 1 The Stages of implementation of the group counselling session was carried out

\begin{tabular}{|c|c|c|c|}
\hline Session & Approach & Goals & Results of Session Analysis \\
\hline 1 & $\begin{array}{l}\text { "Who am I" activity and } \\
\text { sharing }\end{array}$ & $\begin{array}{l}\text { Build rapport and } \\
\text { therapeutic } \\
\text { environment }\end{array}$ & $\begin{array}{l}\text { Towards life prosperity, support } \\
\text { and self-motivation to always } \\
\text { resilience. }\end{array}$ \\
\hline 2 & $\begin{array}{l}\text { Self-disclosed sharing } \\
\text { approach on self- } \\
\text { management }\end{array}$ & $\begin{array}{l}\text { Experience and self- } \\
\text { management sharing } \\
\text { aspect }\end{array}$ & $\begin{array}{l}\text { Body hygiene management, } \\
\text { nutrition management, health } \\
\text { level, stress management and } \\
\text { self-motivation. }\end{array}$ \\
\hline 3 & Drawing and exploring & $\begin{array}{l}\text { Self-potential in self- } \\
\text { management }\end{array}$ & $\begin{array}{l}\text { Able to manage oneself } \\
\text { sometimes in need of social } \\
\text { support. }\end{array}$ \\
\hline 4 & Follow-up session & Self-ability & $\begin{array}{l}\text { The present and future desires in } \\
\text { terms of self-reliance and social } \\
\text { support social as well as self- } \\
\text { prosperity. }\end{array}$ \\
\hline 5 & Reflection and discussion & Disclosure & $\begin{array}{l}\text { To enhance self-motivation in } \\
\text { providing the motivation and } \\
\text { social support that is significant } \\
\text { for self-management. To } \\
\text { emphasize changes in group } \\
\text { members and help each other } \\
\text { for emotional and behavioral } \\
\text { change. Give each member a } \\
\text { positive approval and praise. }\end{array}$ \\
\hline
\end{tabular}

Group counselling is a relationship between an individual and another individual in a group that focuses on the same aspect of the problem in the context of behavior and includes the involvement of therapeutic or recovery functions. This can be seen from the five sessions conducted in which the members of each group played a role and were able to provide good feedback when one of the other group members shared their story.

Consequently, the results from findings and sharing have also encouraged support in motivating themselves to rise towards the well-being of group members and to build confidence in the community. At the end of the session, it gives awareness to group members that this life requires courage and positive thoughts for group members with the application of good emotional control as well as aspects of self-management that lead to well-being which directed towards good mental health. As such, group counselling services can be one of the support systems for former mental health patients from all aspects of life, especially recognizing that selfmanagement needs to be managed in pursuing self-reliance and rising self-motivation to achieve a better life. In addition, the supportive environment in this group can also make group members more confident in learning and practicing new behaviors learned through this group. Group members will be able to learn new social skills as well as to improve existing social skills and also to help them to interact in healthy ways.

Gibson and Mitchell (1981) define group counselling as a process of helping a client to adapt to their daily routine in the form of their behavior, personal relationships, self-esteem, and attitudes in line with their individual skills. In this regard, the implementation of group counselling is seen as an effective platform in helping members to solve problems in their environment and the issues they raise through discussion, sharing ideas and information in finding the most appropriate and definite solution. The results of the discussion favored by group member, has a positive impact on the other group members. Having illness does not prevent them from doing good and their self-esteem is important for maintaining positive behaviors among them.

Furthermore, attention should be given for group counselling especially on mental health issues, where the focus is for the former group of mental health patients on the aspect of self-management. In this regard, this group counselling service can assist them in psychology and self-management as well as guidance for their well-being. In the meantime, improvements that can be made for future studies by increasing the frequency of sessions and making group counselling services as one of the support systems for former mental patients. 


\section{Conclusions}

Fortunately, this research achieved the goal of developing a self-confidence in dealing with the community among former mental health patients. In addition, the results of discussions and sharing have also encouraged and supported the respondents' self-motivation to rise towards self-management well-being. At the end of the session, it gives awareness to group members that this life requires courage and positive thoughts for group members in a supportive environment and it also enables members to be more confident in learning and practicing new behaviours learned through this group. Group members will be able to learn new social skills as well as improve existing social skills as some group members have antisocial problems. It also helps them interact with each other and help each other by sharing their information, experiences, feelings and thoughts

\section{References}

Ahmad Nabil, M., Marhani M., \& Azlin, B. (2014). Managing Schizophrenia in the Midst of Schizophrenia The Role of Assertive Community Treatment. Med \& Health. 9(2): 139- 142.

Degges-White, S. \& Stoltz, K. (2014). Archetypal Identity Development, Meaning in Life, and Life Satisfaction: Differences among Clinical Mental Health Counselors, School Counselors, and Counselor Educators. The American Counseling Association.

Gibson, R.L., \& Mitchell, M.H. (1981). Introduction to guidance. New York: Macmillan Publication.

Intan Nur Haila Meor Safari, Nor Lija Kassim, Nur Falihan Iskandar, Mohamad Haazik Mohamed \& Mohd Yusof Hj Abdullah. (2011). Tahap Pengetahuan Mengenai Kesihatan Mental dalam Kalangan Pelajar Institusi Pengajian Tinggi Awam (IPTA): Kajian Kes di Universiti Kebangsaan Malaysia, Bangi.

Mohamed \& Mohd Yusof Hj Abdullah. (2011). Tahap Pengetahuan Mengenai Kesihatan Mental dalam Kalangan Pelajar Institusi Pengajian Tinggi Awam (TPTA): Kajian Kes di Universiti Kebangsaan Malaysia,Bangi. Muh. Arba'in. (2012). Gender dan Kehutanan Masyarakat. Jogjakarta.

Porter, J.F., Spates C.R., \& Smitham, S. (2004). Behavioral Activation Group Therapy in Public Mental Health Settings: A Pilot Investigation. Professional Psychology: Research and Practice.

Powell, T., \& Perron, B.E. (2010). Self-Help Groups and Mental Health/Substance Use Agencies: The Benefits of Organizational Exchange. Substance Use \& Misuse, 45:315-329.

Rogers, C.R. (1951). Client-centered therapy. Boston: Houghton Mifflin.

Roslee Ahmad, Mohamed Sharif Mustaffa, \& Jamaludin Ramli. (2005). Kesihatan Mental Rakyat Malaysia Masa Kini Suatu Pendekatan Kaunseling Berdasarkan Nilai-Nilai Islam. Universiti Teknologi Malaysia, Skudai.

Tzschach, A., \& Ropers, H.H. (2007). Genetic of Mental Retardation. Dtsch Arztebl. 104(20): A 1400-5. http://www.aerzteblatt.de. 